\title{
Features of structure formation of dispersively filled with microcomposites with a polypropylene matrix
}

\author{
N. Fialko ${ }^{1} \bullet$ R. Dinzhos ${ }^{2} \bullet$ Ju. Sherenkovskiy ${ }^{1} \bullet$ N. Meranova ${ }^{1} \bullet$ R. Navrodska ${ }^{1}$ \\ ${ }^{1}$ Institute of Engineering Thermophysics of NAS of Ukraine, Kyiv, Ukraine; \\ ${ }^{2}$ V.O. Sukhomlynskyi Mykolaiv National University, Mykolaiv, Ukraine
}

Received: 07 April 2020 / Accepted: 25 May 2020

\begin{abstract}
Backgrounds. The regularities of the structure formation of polymer microcomposite materials during their cooling from the melt are established.

Objective. The aim of the work is to study the crystallization features of microcomposites based on a polypropylene matrix with a filler in the form of aluminum microparticles.

Methods. The research technique includes two stages: the experimental receipt of crystallization exotherms and, based on them, the theoretical determination of the main characteristics of the structure formation process.

Results. The patterns of composites crystallization were studied in a wide range of changes in the melt cooling rate and the mass fraction of filler for microcomposites obtained by two methods, the first of which is based on mixing the components in dry form, the second - in the polymer melt. An analysis of the structure formation mechanisms of the studied composites at the nucleation stage and at the stage of structures formation in the melt volume is made.

Conclusions. It is shown that at the first of the indicated stages, a planar and volumetric crystallization mechanism is realized with some prevalence of the volumetric one. At the second stage, when using the method of producing composites, based on the mixing of components in a dry form, a tense matrix mechanism takes place; when implementing the method of mixing components in a polymer melt, the structure formation mechanism depends on the mass fraction of the filler.
\end{abstract}

Keywords: polymer microcomposites; structure formation mechanisms, crystallization exotherms; microcomposites production methods

\section{Introduction}

Among the synthetic materials, which significantly displaced traditional natural materials in modern production, polymer microcomposites occupy a special place. This is largely due to the wide variety of their properties, the possibility of production new composites due to the special choice of their components - both the type of polymer matrix, and the material and concentration of the filler. In this case, it is possible to create composites with the required set of pro-perties (strength, deformation, heat-conducting, etc.), oriented to the specific conditions of their operation[1-12].

The development of polymer composite materials with the necessary combination of properties is based on comprehensive research, including the selection of the polymer matrix material, the type and mass fraction of the filler, the study of the structural formation of the composites depending on the method of their producing, its technological parameters, etc.

The aim of this work is to establish the patterns of structure formation of polymer microcomposites with a polypropylene matrix filled with aluminum microparticles.

\section{Research methods and materials used}

The experimental calculation method for studying crystallization processes included two stages. The first stage consisted of constructing experimental crystallization exotherms of the composite during its cooling from the melt at a

N.M. Fialko

nmfialko@ukr.net
Ju.V. Sherenkovsky

j_sher@ukr.net
R. Dinzhos

dinzhosrv@gmail.com 
given constant velocity. In this case, the sample placed in the cell was heated to a temperature exceeding the polymer melting point by $50 \mathrm{~K}$, kept at this temperature for $180 \mathrm{~s}$ and then cooled to $400 \mathrm{~K}$ at a fixed cooling velocity $\left(V_{t}=0.00833 \ldots 0.333 \mathrm{~K} / \mathrm{s}\right)$. The specific heat flux removed from the composite was determined in a dry nitrogen atmosphere by method of differential scanning calorimetry using a Perkin-Elmer DSC-2 instrument with modified software from IFA GmbUlm. The second stage was the theoretical determination based on the obtained experimental data of the characteristics of the crystallization process:

a) at the stage of nucleation of individual structurally ordered subregions using the nucleation equation

$$
\ln \left\{V_{t}\left[(m+1) T_{N}-T_{\mathrm{M}}\right]\left(T_{\mathrm{M}}\right)^{m} / T_{N}^{2}(\Delta T)^{m+1}\right\}=\ln \left(K_{m} / a_{m}\right)-a_{m}\left(T_{\mathrm{M}}\right)^{m} / T_{N}(\Delta T)^{m}
$$

$b$ ) at the stage of formation of such structures in the entire volume of the composite using the standard and modified Kolmogorov-Avrami equations

$$
\begin{gathered}
\alpha(\tau)=1-\exp \left(-K_{n} \tau^{n}\right) \\
\alpha(\tau)=f\left[1-\exp \left(-K_{n}^{\prime} \tau^{n^{\prime}}\right)\right]+(1-f) \cdot\left[1-\exp \left(-K_{n}^{\prime \prime} \tau^{n^{\prime \prime}}\right)\right],
\end{gathered}
$$

where $a_{m}$ is the reduced nucleation parameter; $f$ is the relative volume fraction of the crystalline phase corresponding to crystallization on fluctuations in the density of the polymer; $K_{m}$ - reduced transport barrier; $K_{n}-$ is the effective velocity constant; $m$ is the dimensionless form parameter; $n$ is the pseudo-parameter of the form; $T$ is the temperature; $T_{N}, T_{K}$ - temperature of the beginning and end of crystallization; $\Delta T$ is the crystallization temperature range; $T_{M}-$ melt temperature corresponding to the maximum value of specific heat flux $Q_{n}=Q_{n}^{\max } ; \alpha$ is the relative volume fraction of the crystalline phase; $\tau$ is the reduced time, $\tau=V_{t} \cdot t ; t$ is time, $V_{t}$ is the cooling velocity; the superscripts " " " and " " " correspond to the crystallization mechanism on fluctuations of polymer density and on filler nanoparticles, respectively.

As for the experimental methods for producing polymer composites, two methods were used in the work: method I, based on the mixing of components that are in dry form, using a magnetic stirrer and an ultrasonic dispersant and then with hot pressing of the resulting composition, and method II, which is based on mixing components in the polymer melt with the use of a disk extruder with further molding of the composite into the required form by hot pressing.

Composites based on a polypropylene matrix were investigated. The aluminum microparticles used as a dispersed filler were made of aluminum chips by grinding them in a ball mill until particles $(0.5 \ldots 1)$ micron in size were formed.

\section{Research results}

The main results of the research first stage aimed at experimental obtaining exotherms of crystallization of the studied microcomposites by both methods under consideration are shown in Fig. 1 and Table 1.

The experimentally obtained crystallization exotherms were used to theoretically analyze the structural features of the polymer microcomposites under consideration. To determine the characteristics of structure formation at the initial stage of crystallization, the nucleation equation was solved for two values of the shape parameter, $\mathrm{m}=1$ and $\mathrm{m}=2$, corresponding to planar and volumetric mechanisms of structure formation, respectively. Studies were conducted for various values of the mass fraction of the filler. The calculation data are presented in table 2 for the two methods under consideration.

As for the second stage of crystallization - the stage of structure formation in the bulk of the composite, two mechanisms of crystal formation were studied here. In the first of them, the main role is played by the polymer matrix itself (crystallization occurs on fluctuations in the polymer density); in the second one the main role belongs to filler particles serving as crystallization centers. In accordance with this, the analysis of experimental crystallization exotherms was carried out for the first case using the Kolmogorov - Avrami equation (2), for the second one, its modified version (3) was used, see table 3.

As follows from the data presented (Table 1), the influence of the method of producing polymer composites on the characteristic crystallization temperatures is small. When the components are mixed in dry form (method I), the temperatures of the onset $\mathrm{TN}$ and the end $\mathrm{TK}$ of crystallization are generally lower than when they are mixed in a polymer melt (method II). Moreover, the differences in TN do not exceed half a degree, and in TK they are $0 \ldots 0.4 \mathrm{~K}$ for small values of the mass fraction of the filler $\omega(\omega=0.2-0.3 \%)$, and $1.5 \ldots 2.0 \mathrm{~K}$ for values $\omega=1.0-4.0 \%$. 

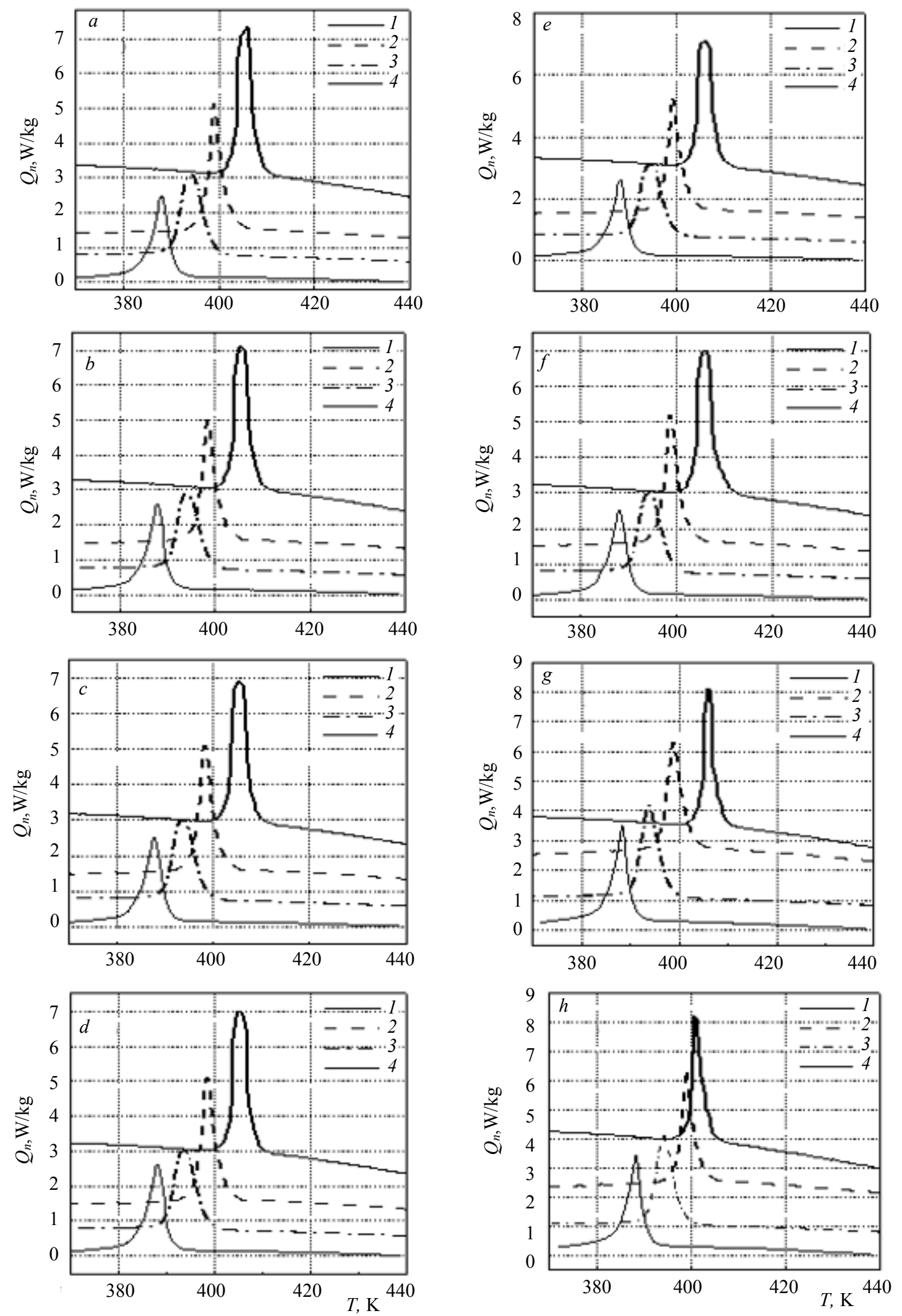

Fig. 1. The crystallization exotherms of polymer microcomposites based on polypropylene, filled with aluminum microparticles, with their mass fraction $\omega=0.2 \%(a, e), 0.3 \%(b, f), 1.0 \%(c, g), 4.0 \%(g, h)$ under the conditions of obtaining composites by method I $(a-d)$ and method II $(d-h)$ for different cooling velocity from the melt $V_{t}$ : $1-V_{t}=0.00833 \mathrm{~K} / \mathrm{s} ; 2-0.0333 \mathrm{~K} / \mathrm{s} ; 3-0.0833 \mathrm{~K} / \mathrm{s} ; 4-0.333 \mathrm{~K} / \mathrm{s}$ 
Table 1. Characteristics of the crystallization process of polymer polypropylene microcomposites filled with aluminum microparticles at various methods for their producing

\begin{tabular}{|c|c|c|c|c|c|c|c|c|c|c|c|}
\hline$\omega, \%$ & $T_{N}, \mathrm{~K}$ & $T_{\mathrm{M}}, \mathrm{K}$ & $T_{K}, \mathrm{~K}$ & $\begin{array}{c}\Delta T \\
\mathrm{~K}\end{array}$ & $\begin{array}{l}Q_{n}^{\max }, \\
\mathrm{W} / \mathrm{kg}\end{array}$ & $\omega, \%$ & $T_{N}, \mathrm{~K}$ & $T_{\mathrm{M}}, \mathrm{K}$ & $T_{K}, \mathrm{~K}$ & $\begin{array}{c}\Delta T \\
\mathrm{~K}\end{array}$ & $\begin{array}{l}Q_{n}^{\max }, \\
\mathrm{W} / \mathrm{kg}\end{array}$ \\
\hline \multicolumn{6}{|c|}{ Method I } & \multicolumn{6}{|c|}{ Method II } \\
\hline \multicolumn{12}{|c|}{$V_{t}=0,00833 \mathrm{~K} / \mathrm{s}$} \\
\hline 0,2 & 410,1 & 405,9 & 401,2 & 8,9 & 7,3 & 0,2 & 410,2 & 406,2 & 401,2 & 9,0 & 7,1 \\
\hline 0,3 & 409,9 & 405,7 & 400,9 & 9,0 & 7,1 & 0,3 & 410,1 & 406,0 & 401,2 & 8,9 & 7,0 \\
\hline 1,0 & 409,8 & 405,5 & 400,7 & 9,1 & 6,9 & 1,0 & 410,0 & 406,1 & 402,2 & 7,8 & 8,1 \\
\hline 4,0 & 409,6 & 405,4 & 400,6 & 9,0 & 7,0 & 4,0 & 409,9 & 406,1 & 402,3 & 7,6 & 8,2 \\
\hline \multicolumn{12}{|c|}{$V_{t}=0,0333 \mathrm{~K} / \mathrm{s}$} \\
\hline 0,2 & 403,6 & 398,9 & 394,1 & 9,5 & 5,1 & 0,2 & 404.0 & 399,1 & 394,3 & 9,7 & 5,3 \\
\hline 0,3 & 403,5 & 398,7 & 394,0 & 9,5 & 5,0 & 0,3 & 403,7 & 398,9 & 394,3 & 9,4 & 5,2 \\
\hline 1,0 & 403,2 & 398,5 & 393,9 & 9,3 & 5,1 & 1,0 & 403,5 & 399,0 & 395,6 & 7,9 & 6,3 \\
\hline 4,0 & 403,2 & 398,6 & 393,8 & 9,4 & 5,1 & 4,0 & 403,6 & 399,1 & 395,8 & 7,8 & 6,4 \\
\hline \multicolumn{12}{|c|}{$V_{t}=0,0833 \mathrm{~K} / \mathrm{s}$} \\
\hline 0,2 & 401,2 & 394,2 & 389,2 & 12,0 & 3,1 & 0,2 & 401,5 & 394,6 & 389,4 & 12,1 & 3,1 \\
\hline 0,3 & 401,0 & 394,2 & 388,9 & 12,1 & 2,9 & 0,3 & 401,3 & 394,3 & 389,3 & 12,0 & 3,0 \\
\hline 1,0 & 400,7 & 393,9 & 388,5 & 12,2 & 3,0 & 1,0 & 401,0 & 394,0 & 390,1 & 10,9 & 4,2 \\
\hline 4,0 & 400,7 & 393,8 & 388,6 & 12,1 & 3,0 & 4,0 & 401,2 & 394,1 & 390,2 & 11,0 & 4,1 \\
\hline \multicolumn{12}{|c|}{$V_{t}=0,3333 \mathrm{~K} / \mathrm{s}$} \\
\hline 0,2 & 394,8 & 388,0 & 381,1 & 13,7 & 2,5 & 0,2 & 395,0 & 388,1 & 381,2 & 13,9 & 2,6 \\
\hline 0,3 & 394,7 & 387,9 & 380,9 & 13,8 & 2,6 & 0,3 & 394,9 & 388,2 & 381,1 & 13,8 & 2,5 \\
\hline 1,0 & 394,6 & 387,8 & 381,0 & 13,6 & 2,5 & 1,0 & 394,6 & 388,3 & 383,0 & 11,6 & 3,5 \\
\hline 4,0 & 394,4 & 388,0 & 381,2 & 13,2 & 2,6 & 4,0 & 394,2 & 388,2 & 382,8 & 11,4 & 3,4 \\
\hline
\end{tabular}

Table 2. Parameters of structure formation at the initial stage of crystallization of polypropylene polymer microcomposites filled with aluminum microparticles at various methods for their producing

\begin{tabular}{|c|c|c|c|c|c|c|}
\hline$\omega, \%$ & $a_{1}, \mathrm{~K}$ & $K_{1}, 1 / \mathrm{c}$ & $R_{l}$ & $a_{2}, 10^{-6} \mathrm{~K}$ & $K_{2}, 1 / \mathrm{c}$ & $R_{2}$ \\
\hline \multicolumn{7}{|c|}{ Method I } \\
\hline 0,0 & 0,175 & 0,0110 & 0,8842 & 3,61 & 2,13 & 0,9995 \\
\hline 0,2 & 0,183 & 0,0095 & 0,8789 & 3,98 & 1,58 & 0,9951 \\
\hline 0,3 & 0,184 & 0,0092 & 0,8731 & 4,00 & 1,53 & 0,9937 \\
\hline 1,0 & 0,197 & 0,0071 & 0,8692 & 4,04 & 1,39 & 0,9911 \\
\hline 4,0 & 0,208 & 0,0034 & 0,8779 & 4,09 & 1,09 & 0,9923 \\
\hline \multicolumn{7}{|c|}{ Method II } \\
\hline 0,0 & 0,175 & 0,0110 & 0,8842 & 3,61 & 2,13 & 0,9995 \\
\hline 0,2 & 0,177 & 0,0099 & 0,8289 & 3,72 & 1,69 & 0,9931 \\
\hline 0,3 & 0,179 & 0,0094 & 0,8311 & 3,77 & 1,62 & 0,9927 \\
\hline 1,0 & 0,195 & 0,0076 & 0,9018 & 4,21 & 1,41 & 0,9911 \\
\hline 4,0 & 0,218 & 0,0031 & 0,9039 & 4,28 & 1,26 & 0,9923 \\
\hline
\end{tabular}


Table 3. Parameters of structure formation at the crystallization stage in the volume of polypropylene-based polymer microcomposites filled with aluminum microparticles at various methods for their producing

\begin{tabular}{|c|c|c|c|c|c|c|c|c|c|}
\hline \multirow{2}{*}{$\omega, \%$} & \multirow{2}{*}{$\begin{array}{c}V_{t} \\
\mathrm{~K} / \mathrm{s}\end{array}$} & \multicolumn{3}{|c|}{ Equation (2) } & \multicolumn{5}{|c|}{ Equation (3) } \\
\hline & & $n$ & $K_{n}, 10^{-5} \mathrm{~K}^{-n}$ & $\chi^{2}, 10^{-5}$ & $f$ & $K_{n}^{\prime}, 10^{-5} \mathrm{~K}^{-\mathrm{n}^{\prime}}$ & $n^{\prime \prime}$ & $K_{n}^{\prime \prime}, 10^{-5} \mathrm{~K}^{-n^{\prime \prime}}$ & $\chi^{2}, 10^{-5}$ \\
\hline \multirow{4}{*}{0,2} & 0,0083 & 4,9 & 182 & 79 & 0,86 & 83 & 4,6 & 311 & 4 \\
\hline & 0,0333 & 4,9 & 195 & 83 & 0,85 & 91 & 4,6 & 267 & 7 \\
\hline & 0,0833 & 4,8 & 204 & 73 & 0,88 & 54 & 4,4 & 231 & 4 \\
\hline & 0,3333 & 4,8 & 237 & 92 & 0,85 & 39 & 4,4 & 201 & 7 \\
\hline \multirow{4}{*}{0,3} & 0,0083 & 4,8 & 186 & 101 & 0,84 & 58 & 4,6 & 364 & 9 \\
\hline & 0,0333 & 4,8 & 197 & 94 & 0,85 & 64 & 4,3 & 301 & 8 \\
\hline & 0,0833 & 4,8 & 223 & 88 & 0,85 & 49 & 4,3 & 264 & 5 \\
\hline & 0,3333 & 4,7 & 247 & 69 & 0,86 & 52 & 4,4 & 197 & 2 \\
\hline \multirow{4}{*}{1,0} & 0,0083 & 4,8 & 184 & 87 & 0,87 & 67 & 4,1 & 123 & 6 \\
\hline & 0,0333 & 4,7 & 193 & 94 & 0,85 & 41 & 4,1 & 169 & 7 \\
\hline & 0,0833 & 4,6 & 294 & 99 & 0,88 & 63 & 4,0 & 281 & 8 \\
\hline & 0,3333 & 4,6 & 351 & 101 & 0,84 & 59 & 3,9 & 397 & 3 \\
\hline \multirow{4}{*}{4,0} & 0,0083 & 5,1 & 195 & 106 & 0,84 & 61 & 4,0 & 163 & 11 \\
\hline & 0,0333 & 4,9 & 201 & 97 & 0,86 & 39 & 4,0 & 203 & 3 \\
\hline & 0,0833 & 4,8 & 289 & 59 & 0,88 & 79 & 3,9 & 265 & 3 \\
\hline & 0,3333 & 4,9 & 346 & 78 & 0,87 & 101 & 3,8 & 312 & 5 \\
\hline \multicolumn{10}{|c|}{ Method II } \\
\hline \multirow{4}{*}{0,2} & 0,0083 & 5,0 & 170 & 81 & 0,82 & 71 & 4,8 & 309 & 6 \\
\hline & 0,0333 & 4,9 & 156 & 69 & 0,81 & 67 & 4,8 & 290 & 2 \\
\hline & 0,0833 & 4,9 & 196 & 70 & 0,81 & 94 & 4,6 & 248 & 3 \\
\hline & 0,3333 & 4,8 & 206 & 83 & 0,82 & 49 & 4,7 & 223 & 6 \\
\hline \multirow{4}{*}{0,3} & 0,0083 & 4,9 & 175 & 56 & 0,81 & 51 & 4,8 & 334 & 4 \\
\hline & 0,0333 & 4,9 & 162 & 75 & 0,82 & 56 & 4,7 & 298 & 5 \\
\hline & 0,0833 & 4,8 & 189 & 64 & 0,85 & 75 & 4,7 & 264 & 8 \\
\hline & 0,3333 & 4,8 & 213 & 94 & 0,84 & 71 & 4,6 & 202 & 4 \\
\hline \multirow{4}{*}{1,0} & 0,0083 & 5,0 & 198 & 89 & 0,83 & 56 & 3,2 & 148 & 5 \\
\hline & 0,0333 & 4,8 & 209 & 90 & 0,84 & 82 & 3,3 & 178 & 2 \\
\hline & 0,0833 & 4,9 & 286 & 91 & 0,82 & 89 & 3,4 & 234 & 1 \\
\hline & 0,3333 & 4,8 & 331 & 78 & 0,84 & 61 & 3,2 & 293 & 6 \\
\hline \multirow{4}{*}{4,0} & 0,0083 & 5,1 & 204 & 82 & 0,86 & 79 & 3,0 & 162 & 2 \\
\hline & 0,0333 & 5,1 & 263 & 56 & 0,85 & 47 & 3,0 & 187 & 5 \\
\hline & 0,0833 & 5,2 & 299 & 49 & 0,82 & 31 & 3,3 & 231 & 4 \\
\hline & 0,3333 & 4,8 & 356 & 37 & 0,81 & 89 & 3,2 & 254 & 6 \\
\hline
\end{tabular}

The differences in the temperature ranges of crystallization $\Delta T$ for the compared methods are more complex. At $\omega=0.2 \%, \Delta T$ values for method I are slightly lower (by $0.1-0.2 \mathrm{~K}$ ) than for method II. For large values of $\omega$ ( $\omega=0.3-4.0 \%$ ), the opposite is true: $\Delta T$ for method I become higher than for method II, and the differences between them increase with increasing $\omega$, reaching $2 \mathrm{~K}$ at high cooling velocities. The method of producing microcomposites also affects the value $\left(Q_{n}^{\max }\right)$ and position $\left(T_{M}\right)$ of the maximum specific heat flux (see Fig. 1, Table 1). The discrepancies between the values $Q_{n}^{\max }$ found using different methods depend on the mass fraction $\omega$ of the filler. For small $\omega$, these discrepancies are small (not more than $0.2 \mathrm{~W} / \mathrm{kg}$ ), but may have different signs. For large $\omega(\omega=$ $=1.0-4.0 \%$ ), the values of $Q_{n}^{\max }$ for composites obtained by method II are always higher than when using method I (the differences are $0.8-1.3 \mathrm{~W} / \mathrm{kg}$ ). The temperature of the $T_{M}$ corresponding to the maximum heat flux $Q_{n}^{\max }$ for all the studied parameter values for method II is by $0.1-0.7 \mathrm{~K}$ higher than for method I.

As for the influence of the cooling velocity $V_{t}$, it follows from the obtained data that an increase in $V_{t}$ from values of $0.00833 \mathrm{~K} / \mathrm{s}$ to $0.333 \mathrm{~K} / \mathrm{s}$ leads to a very significant change in the main characteristics of the crystallization process of the considered polymer microcomposites. In this case, the temperatures of the beginning and end of crystallization decrease by $15.2 \ldots 15.7 \mathrm{~K}$ and $19.2 \ldots 20.1 \mathrm{~K}$, respectively, and the temperature range of crystallization increases 
by $3.8 \ldots 4.9 \mathrm{~K}$; the value of the maximum specific heat flux $Q_{n}^{\max }$ increases by $2.3 \ldots 2.9$ times, and the corresponding temperature of the $T_{M}$ decreases by $17.4 \ldots 18.1 \mathrm{~K}$.

The results obtained indicate a quite satisfactory correlation between the calculated and experimental data (Table 2). From an analysis of the data presented, it follows that under the considered conditions both crystallization mechanisms, both planar and volume, occur. However, since the values of the correlation coefficient $R_{2}$ for all the given data exceed the corresponding values of the correlation coefficient $R_{1}$, we can conclude that there is some predominance of the volumetric mechanism over the planar one.

It should be noted that the dependence of the degree of the indicated predominance on the mass fraction of the filler $\omega$ is related to the method used to produce the microcomposite. If this dependence is practically absent for method I, then for method II, for $\omega=0.2 \ldots 0.3 \%$, the degree of this predominance increases, and for $\omega=1 \ldots 4 \%$ it decreases, becoming smaller than for the case of an unfilled polymer $(\omega=0)$.

The obtained calculation results show (see Table 3) that during crystallization on fluctuations of the polymer density, the values of the pseudoparameter of form $n$ in the entire investigated area of parameter changes lie in the range $n=4.6 \ldots 5.2$, which indicates the implementation of the strained matrix mechanism under these conditions.

During crystallization on particles of the filler, the method of producing a microcomposite is affected by the structure formation features. When using method I, crystallization occurs in accordance with the mechanism of the strained matrix (for all considered values of the mass fraction of filler $\omega$ and cooling velocity $V_{t}$, the pseudoparameter of the form $n^{\prime \prime}$ varies in the range $n^{\prime \prime}=3.8 \ldots 4.6$ ). For composites producing by method II, the crystallization mechanism substantially depends on the mass fraction of filler $₫$. For small values of $₫(\omega<0.3 \%)$, the mechanism of the stressed matrix is realized (the pseudoparameter of the form is $\left.n^{\prime \prime}=4.6 \ldots .4 .8\right)$, and for large values of $\omega(\omega=1 \ldots 4 \%)$ the crystallization mechanism under consideration becomes three-dimensional, three-dimensional $\left(n^{\prime \prime}=3.0 \ldots 3.4\right)$.

\section{Conclusions}

A complex of experimental and computational studies of the structure formation processes of polymer microcomposites based on polypropylene using aluminum microparticles as a filler has been performed.

Data on the characteristics of these processes for two methods of producing the materials under consideration methods based on the mixing of components in dry form and in polymer melt were obtained. The regularities of the influence of such factors as the mass fraction of the filler and the cooling velocity of the composite from the melt on the structure formation parameters of the studied polymer composites were established.

\section{References}

1. Zhang, C., Song, J., Huang, T., Zheng, H., He, T. "Increasing lithium extraction performance by adding sulfonated poly (ether ether ketone) into block-copolymer ethylene vinyl alcohol membrane", Journal of Chemical Technology and Biotechnology. - 2020. - Vol. 95, No. 5. P. 1559-1568. https://doi.org/10.1002/jctb.6350

2. Liu, B., Zong, M., Liu, Z., Wu, W. "Influence of Epoxidized Ethylene Propylene Diene Rubber on Nonisothermal Crystallization Kinetics of PBT/GF Composite", Huadong Ligong Daxue Xuebao / Journal of East China University of Science and Technology. - 2020. - Vol. 46, No. 2. P. 219-226. doi: 10.14135/j.cnki.1006-3080.20190116004

3. Gonzalez-Rodriguez, V., Escobar-Barrios, V., Peña-Juárez, M.G., Pérez, E., Gonzalez-Calderon, J.A. "Effect of aliphatic chain in dicarboxylic acids on non-isothermal crystallization and mechanical behavior of titanium dioxide/iPP composites", Thermochimica Acta. - 2020. - Vol. 686, No. 178543. https://doi.org/10.1016/j.tca.2020.178543

4. Luo, J.-H., Han, S.-H., Wang, J., Liu, H., Zhu, X.-D., Chen, S.-H. "Effects of boric acid ester modified magnesium borate whisker on the mechanical properties and crystallization kinetics of polypropylene composites", Materials. - 2020. - Vol. 13. No. 1698. https://doi.org/10.3390/ma13071698

5. Hao, T., Xu, D., Ming, Y., Zhang, S., Wei, Y., Zhou, Z., Nie, Y., Yan, D. "Correlation between molecular weight and confined crystallization behavior of polymers grafted onto a zero-dimensional filler". CrystEngComm. - 2020. - Vol. 22, P. 1779-1788. https://doi.org/10.1039/C9CE01606F

6. Sun, A., Luo, F., Chen, R., Guo, J., Guo, S., Zhang, S. "Effects of sepiolite on crystallization behaviors and properties of sepiolite/polyoxymethylene composites", Journal of Polymer Research. - 2020. - Vol. 27, No. 67.

https://doi.org/10.1007/s10965-020-2012-1

7. Wang, H.-T., Chen, E.-C., Wu, T.-M. "Crystallization and Enzymatic Degradation of Maleic Acid-Grafted Polybutylene adipate-co-terephthalate) / Organically Modified Layered Zinc Phenylphosphonate Nanocomposites", Journal of Polymers and the Environment. - 2020. - Vol. 28, P. 834-843. https://doi.org/10.1007/s10924-019-01647-0

8. Deetuam, C., Samthong, C., Choksriwichit, S., Somwangthanaroj, A. "Isothermal cold crystallization kinetics and properties of thermoformed poly (lactic acid) composites: effects of talc, calcium carbonate, cassava starch and silane coupling agents", Iranian Polymer Journal. - 2020. - Vol. 29, P. 103-116. https://doi.org/10.1007/s13726-019-00778-4 
9. Долинский А.А., Фиалко Н.М., Динжос Р.В., Навродская Р.А. Теплофизические свойства полимерных микро- и нанокомпозитов на основе поликарбоната Промышленная теплотехника. - 2015. - Т. 37, № 2. - С. 12-18.

10. Дінжос Р.В., Фіалко Н.М., Лисенков Е.А. Аналіз теплопровідності полімерних нанокомпозитів наповнених вуглецевими нанотрубками та технічним вуглецем. Journal of Nanoscience and Electronic Physics. - 2014. - T. 6, № 1. C. 01015-1 - 01015-6.

11. Долинский А.А., Фиалко Н.М., Динжос Р.В., Навродская Р.А. Структурообразование полимерных микро - и нанокомпозитов на основе поликарбоната в процессе их кристаллизации. Промышленная теплотехника. - 2015. Т. 37, № 3. - С. 5-15.

12. Долинский А.А., Фиалко Н.М., Динжос Р.В., Навродская Р.А. Теплофизические характеристики высокотеплопроводных полимерных микро- и нанокомопозитов. Промышленная теплотехника. - 2015. - Т. 37, № 5. - C. 5-15.

\title{
Особенности структурообразования дисперснонаполненных микрокомпозитов с полипропиленовой матрицей
}

\author{
Н. М. Фиалко, Р. В. Динжос, Ю. В. Шеренковский, Н. О. Меранова, Р. А. Навродская
}

Проблематика. Установлены закономерности структурообразования полимерных микрокомпозиционных материалов при их охлаждении из расплава. Цель работы состоит в изучении особенностей кристаллизации микрокомпозитов на основе полипропиленовой матрищь с наполнителем в виде микрочастии алюминия.

Методика исследований включает два этапа: экспериментальное получение экзотерм кристаллизации и на их основе теоретическое определение основных характеристик процесса структурообразования.

Результаты. Изучены закономерности кристаллизации композитов в широком диапазоне изменения скорости охлаждения расплава и массовой доли наполнителя для микрокомпозитов, получаемых двумя методами, первый из которых базируется на смешении компонентов в сухом виде, второй-в расплаве полимера. Выполнен анализ механизмов структурообразования изучаемых композитов на стадии нуклеации и на стадии формирования структур в объеме расплава.

Выводы. Показано, что на первой из указанных стадий реализуется плоскостной и объемный механизм кристаллизации при некотором преобладании объемного. На второй стадии при использовании метода получения композитов, базирующегося на смешении компонентов в сухом виде, имеет место механизм напряженной матрищь, при реализации метода смешения компонентов в расплаве полимера - механизм структурообразования зависит от массовой доли наполнителя.

Ключевые слова: полимерные микрокомпозиты; механизмы структурообразования, экзотермы кристаллизации; методы получения микрокомпозитов

\section{Особливості структуроутворення дісперснонаповнених мікрокомпозитів 3 поліпропіленовою матрицею}

\section{Н. М. Фіалко, Р. В. Дінжос, Ю. В. Шеренковський, Н. О. Меранова, Р. А. Навродська}

Проблематика. Встановлено закономірності структуроутворення полімерних мікрокомпозіиійних матеріалів при їх охолодженні з розплаву.

Мета роботи полягає у вивченні особливостей кристалізації мікрокомпозітов на основі поліпропіленової матриці 3 наповнювачем у вигляді мікрочастинок алюмінію.

Методика досліджень включає два етапи: експериментальне отримання екзотерм кристалізації $і$ на їх основі теоретичне визначення основних характеристик прочесу структуроутворення.

Результати. Вивчено закономірності кристалізації композитів в широкому діапазоні зміни швидкості охолодження розплаву і масової частки наповнювача для мікрокомпозітов, що одержані двома методами, перший з яких базується на змімуванні компонентів в сухому вигляді, другий - в розплаві полімеру. Виконано аналіз механізмів структуроутворення досліджуваних композитів на стадії нуклеації і на стадї формування структур в об'ємі розплаву.

Висновки. Показано, що на першій із зазначених стадій реалізується площинний і об'ємний механізм кристалізаиії при деякому переважанні об'ємного. На другій стадї при використанні методу отримання композитів, щзо базується на змішуванні компонентів в сухому вигляді, має місие механізм напруженої матриці, при реалізації методу змішування компонентів в розплаві полімеру - механізм структуроутворення залежить від масової частки наповнювача.

Ключові слова: полімерні мікрокомпозити; механізми структуроутворення, екзотерми кристалізації; методи отримання мікрокомпозитів

\section{References}

1. Zhang, C., Song, J., Huang, T., Zheng, H. and He, T. (2020), "Increasing lithium extraction performance by adding sulfonated poly (ether ether ketone) into block-copolymer ethylene vinyl alcohol membrane", Journal of Chemical Technology and Biotechnology, vol. 95, no. 5, pp. 1559-1568. https://doi.org/10.1002/jctb.6350 
2. Liu, B., Zong, M., Liu, Z. and Wu, W. (2020), "Influence of Epoxidized Ethylene Propylene Diene Rubber on Nonisothermal Crystallization Kinetics of PBT/GF Composite", Journal of East China University of Science and Technology, vol. 46, no. 2, pp. 219-226. doi: 10.14135/j.cnki.1006-3080.20190116004

3. Gonzalez-Rodriguez, V., Escobar-Barrios, V., Peña-Juárez, M.G., Pérez, E. and Gonzalez-Calderon, J.A. (2020), “Effect of aliphatic chain in dicarboxylic acids on non-isothermal crystallization and mechanical behavior of titanium dioxide/iPP composites", Thermochimica Acta, vol. 686, no. 178543. https://doi.org/10.1016/j.tca.2020.178543

4. Luo, J.-H., Han, S.-H., Wang, J., Liu, H., Zhu, X.-D. and Chen, S.-H. (2020), "Effects of boric acid ester modified magnesium borate whisker on the mechanical properties and crystallization kinetics of polypropylene composites", Materials, vol. 13, no. 1698. https://doi.org/10.3390/ma13071698

5. Hao, T., Xu, D., Ming, Y., Zhang, S., Wei, Y., Zhou, Z., Nie, Y. and Yan, D. (2020), "Correlation between molecular weight and confined crystallization behavior of polymers grafted onto a zero-dimensional filler", CrystEngComm, vol. 22, pp. 1779 -1788. https://doi.org/10.1039/C9CE01606F

6. Sun, A., Luo, F., Chen, R., Guo, J., Guo, S. and Zhang, S. (2020), "Effects of sepiolite on crystallization behaviors and properties of sepiolite/polyoxymethylene composites", Journal of Polymer Research, vol. 27, no. 67. https://doi.org/10.1007/s10965-020-2012-1

7. Wang, H.-T., Chen, E.-C. and Wu, T.-M. (2020), "Crystallization and Enzymatic Degradation of Maleic Acid-Grafted Polybutylene adipate-co-terephthalate) / Organically Modified Layered Zinc Phenylphosphonate Nanocomposites", Journal of Polymers and the Environment, vol. 28, pp. 834-843. https://doi.org/10.1007/s10924-019-01647-0

8. Deetuam, C., Samthong, C., Choksriwichit, S. and Somwangthanaroj, A. (2020), "Isothermal cold crystallization kinetics and properties of thermoformed poly (lactic acid) composites: effects of talc, calcium carbonate, cassava starch and silane coupling agents", Iranian Polymer Journal, vol. 29, pp. 103-116. https://doi.org/10.1007/s13726-019-00778-4

9. Dolinskiy, A.A., Fialko, N.M., Dinzhos, R.V. and Navrodskaya, R.A. (2015), "Thermophysical properties of polymer microand nanocomposites based on polycarbonate", Industrial Heat Engineering, vol. 37, no. 2, pp. 12-18.

10. Dinzhos, R.V., Fialko, N.M. and Lysenkov, E.A. (2014), “Analysis of thermal conductivity of polymer nanocomposites filled with carbon nanotubes and carbon black", Journal of Nanoscience and Electronic Physics, vol. 6, no. 1, pp. 01015-1 - 01015-6.

11. Dolinskiy, A.A., Fialko, N.M., Dinzhos, R.V. and Navrodskaya, R.A. (2015), "Structure formation of polymer micro- and nanocomposites based on polycarbonate in the processes of their crystallization", Industrial Heat Engineering, vol. 37, no. 3, pp. 5-15.

12. Dolinsky A.A., Fialko N.M., Dinzhos R.V. and Navrodskaya R.A. (2015), "Thermophysical characteristics of highly heatconducting polymer micro- and nanocomposites, Industrial heat engineering”, vol. 37, no. 5, pp. 5-15. 